\title{
Belgeo
}

Revue belge de géographie

\section{School choice and local embeddedness in Brussels: the neighbourhood effect assessed through administrative files}

Choix de l'école et ancrage local à Bruxelles: une analyse de l'effet du quartier à la lumière des données administratives

Julien Danhier and Perrine Devleeshouwer

\section{(2) OpenEdition}

\section{Journals}

Electronic version

URL: http://journals.openedition.org/belgeo/18999

DOI: 10.4000/belgeo.18999

ISSN: 2294-9135

\section{Publisher:}

National Committee of Geography of Belgium, Société Royale Belge de Géographie

\section{Electronic reference}

Julien Danhier and Perrine Devleeshouwer, « School choice and local embeddedness in Brussels: the neighbourhood effect assessed through administrative files », Belgeo [Online], 2-3 | 2017, Online since 31 December 2016, connection on 19 April 2019. URL : http://journals.openedition.org/belgeo/18999 DOI : 10.4000/belgeo.18999

This text was automatically generated on 19 April 2019

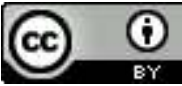

Belgeo est mis à disposition selon les termes de la licence Creative Commons Attribution 4.0 International. 


\title{
School choice and local embeddedness in Brussels: the neighbourhood effect assessed through administrative files
}

\author{
Choix de l'école et ancrage local à Bruxelles: une analyse de l'effet du quartier à \\ la lumière des données administratives
}

Julien Danhier and Perrine Devleeshouwer

The research leading to these results has received funding from the European Research Council under the European Union's Seventh Framework Programme (FP/2007-2013) / ERC Grant Agreement 28360, for the EQUOP-project "Equal opportunities for migrant youth in educational systems with high levels of social and ethnic segregation - assessing the impact of school team resources". It has also receive funding from the Prospective research for Brussels/Innoviris. The authors wish to express their gratitude to Andrew Crosby, Rob Kaelen, Sybille Regout and Dirk Jacobs for helpful comments and assistance.

\section{Introduction}

1 The potential negative effect of growing up in a segregated deprived neighbourhood has been the focus of a rich literature. This effect is called the neighbourhood effect. In their literature review, Jencks and Mayer (1990) listed balanced results about this effect but neighbourhoods seem to influence some outcomes such as the expected educational attainment. Growing up in high-poverty neighbourhoods diminishes the childhood IQ (Brooks-Gunn et al., 1993) and student achievement (Carlson, Cowen, 2015) and increases behaviour problems, out-of-wedlock births, school drop-outs (Brooks-Gunn et al., 1993) and teenage pregnancy (Harding, 2003). It has also been shown that this affects the verbal cognitive ability of black children negatively (Sampson, Sharkey \& Raudenbush, 2008) and the observed cognitive ability across generations (Sharkey, Elwert, 2011). Hence, the 
neighbourhood can influence educational outcomes variables (achievement, drop-out...) but also cognitive variables and life chances variables (teenage pregnancy, IQ, behaviour problems, employment).

The neighbourhood can influence the child and the adolescent outcomes through various dimensions: economic resources, parental characteristics, parenting behaviour, school environments, peer groups or economic opportunities (see the heuristic model in BrooksGunn et al., 1993). In their literature review, Jencks and Mayer (1990) point out three schemes to explain the advantage of growing up in a privileged neighbourhood. Firstly, epidemic models state that behaviours are contagious so that a child would behave better when growing among well-behaved children. For example, Palardy (2015) showed that peer attitude influences the student's college choices. Secondly, institutional models focus on the influence of adults working in institutions of the neighbourhood such as a school or the police. For example, it has been observed that schools in poor neighbourhoods tend to present a lower quality of teaching (Bell, 2003) and have more novice teachers (Clotfelter et al., 2006; Clotfelter, Ladd \& Vigdor, 2005). Thirdly, collective socialization models assume that some adults play the role of a model or an example of success that can influence the children. On the opposite, it is worth noting that growing up in a privileged neighbourhood can also have disadvantages for youth with a more deprived background. Models such as relative deprivation state that success is judged in comparison with the success of others. This can explain why some poor students can have better achievement or self-concept in low-SES school than in high-SES ones (see Dijkstra et al., 2008 for a review; Marsh and Parker, 1984). It is also worth noting that the neighbourhood effect on the youths' educational performances is not obvious. Indeed, quasi-experimental designs or housing policies that allow observing the consequences of shifting the schooling and living conditions of people show that when diverse programs successfully change the environment, improving academic performances is far from evident (DeLuca, Dayton, 2009). Although numerous parents try to reach better schooling for their children, they encounter a multitude of resistances and instabilities that interfere with their daily life (DeLuca, Rosenblatt, 2010).

3 Asserting the existence of a neighbourhood effect is relatively complex as it implies the differentiation of the specific effect of the neighbourhood from individuals and background characteristics. Multilevel modelling has offered possibilities to disentangle these effects. Such techniques have been used for a long time to measure the negative effect of being in a deprived school (Dumay and Dupriez, 2008; Opdenakker, Van Damme, 2001; Sykes, Kuyper, 2013). They have also been used to model clustering in neighbourhood data and to disentangle the effect of the school from the effect of the neighbourhood. Controlling for school effect with dummy variables, Garner and Raudenbush (1991) observed that growing in a deprived neighbourhood has a negative effect on attainment. Recently, the use of cross-classified multilevel modelling allowed modelling simultaneously schools and neighbourhoods. Such research tends to show the importance of the school influence while the effect of the neighbourhood is modest (Brännström, 2008; Sykes, Musterd, 2011).

4 However, this move is not incompatible with the neighbourhood effect and the schemes presented above. It is important to understand one underlying assumption of the neighbourhood effect: the embeddedness. According to Lupton (2006), the large differences across studies on neighbourhood effect could be explained by the fact that the effect strongly depends on the number of students living in the neighbourhood who go to 
the local school. In other words, if students tend to go to local schools, we can expect a large neighbourhood effect especially for these students. On the contrary, in the absence of such an embeddedness, we could expect a lower neighbourhood effect. This implies that the importance of neighbourhood effect will depend on the way pupils are allocated to schools, which strongly depends on the enrolment and distribution policies as well as on the logic of school choices in the school system. According to Bacqué and Fol (2007), studies about the negative consequences of growing up and living in deprived neighbourhoods rely on the idea that the population of those areas suffers from local embeddedness. In other words, it is because they do not or cannot develop mobility practices to leave the neighbourhood that they tend to have a low access to institutions that promote social inclusion and upward social mobility, such as schools or work. Indeed, it has been shown that there are links between multiple segregated contexts (whether it is in the USA or in the EU) and strong identity attachment to the neighbourhood of residence as well as with local embeddedness (André, 2012; Jamoulle, Mazzocchetti, 2011; Jencks, Mayer, 1990; Nagels, Rea, 2007). Moreover, Bacqué and Fol (2007) underline the fact that in neighbourhood effect studies, the local embeddedness is seen as linked with an intrinsic logic of lower social classes. They highlight the fact that too often immobility and local embeddedness are considered negatively while mobility is always valorized as being positive.

5 If the size of the neighbourhood effect depends on the capacity of the inhabitants to access some institutions and particularly to access schools out of the border of the neighbourhood, it is then interesting to question whether or not the neighbourhood influences mobility between the home and the school. According to the literature we have just seen, our main hypothesis is that students living in deprived neighbourhoods develop a smaller mobility to go to their school than students living in other areas. However, in Brussels, two researches question the connection between neighbourhood and mobility. Dujardin, Selod and Thomas (2008) showed that unemployment is exacerbated by residential segregation and that living in a deprived neighbourhood increases the unemployment probability of young adults. However, these deprived neighbourhoods of Brussels are not disconnected from jobs which are concentrated in these areas. On the basis of 40 qualitative semi-structured interviews with students from five different schools in deprived neighbourhoods in Brussels, Devleeshouwer (2014) was not able to observe any particular restriction of the student's mobility or daily life to any specific part of the city. In other words, whether going to school or other activities, an important part of those students covered bigger distances than the others. Hence they did not experience local embeddedness. It is possible that in Brussels, mobility is disconnected from the neighbourhood of the student. This finding will be challenged in the following analyses and our hypothesis is that students in deprived neighbourhoods of Brussels do experience different mobility practices with regards to their school than students in privileged neighbourhoods. Consequently, the variable of interest is the distance covered by students to reach their school. By specifying the dependent variable as the distances covered by students between their house and school in a multilevel modelling, we can explore how the characteristics of the student and of the student's residence are associated with this distance. We test this hypothesis in Brussels because although it is a small city (around 1,200,000 people in a $160 \mathrm{~km}^{2}$ area), it provides an interesting case study. Indeed, its school system corresponds to a small, coherent but segregated market with a dense offer. The competitiveness in this educational market 
(and the consecutive shortage of places in the most appealing schools) makes the families' choice of school capital.

\section{The Brussels French-speaking Case Study}

6 Since 1989, Belgium has three separate educational systems reflecting the division of the country in three linguistic communities. The Dutch and the French-speaking communities deal with the majority of the students' population (respectively about 55 and 44 percent of the students) while less than 1 percent of this population attends schools in the German-speaking Community. The two main educational systems are separately managed but continue to share important similarities in terms of funding rules and structures. In this paper, we will focus only on schools of the French-speaking Community (called Wallonia-Brussels Federation in the following lines) located in the Brussels-Capital Region (improperly called Brussels in the current paper). The Frenchspeaking school system is based on a great freedom of school choice while at the same time it is organized as a poorly regulated quasi-market. Indeed, the Belgian constitution guarantees free education. In particular, it guarantees that parents are free to select the school their child will attend, that the school is free of charge and that the organizing authorities are subsidized. In this context, it is important to note that schools are funded per capita. Consequently, the schools are in competition, and implement specific strategies to attract students (more or less specific) on which public subsidization is mainly based. Studies have shown that the quasi-market's educational policies in Belgium end up segregating students in different schools according to some demographic and/or achievement characteristics, generating both "ghetto" and "sanctuary" schools (Demeuse and Friant, 2010).

7 In this system, families and schools are the two main actors of the reproduction of educational segregation and hierarchies (Delvaux, Joseph, 2006; Devleeshouwer, Rea, 2011). This reproduction occurs by the actions of families and schools in local spaces. In systems based on the freedom of school choice, the spatial configuration of school inequalities is in large part due to the schools' policies of positioning themselves on the quasi-market and to the families' strategies of school choice (de Souza and Leal, 2006). In quasi-market systems, schools tend to develop actions to attract pupils in order to keep their subventions; while families develop strategies of choices to find what they think is the best school for their children. According to Delvaux and Joseph (2006), the hierarchies between schools in the local area constitute a structuring frame for actors' perceptions and practices as families make their choices according to the perceptions they have about this hierarchy.

8 A second characteristic of the educational system is worth noting. In the third grade of secondary education, students have to choose between the academic and the vocational tracks. Structuring the system this way (also known as the "waterfall" system) affects school choice: low achievers in academic tracks tend to switch to vocational curricula. A certain hierarchy of curricula is established as some tracks welcome students whose school career is marked by successive successes and others welcome students whose career is marked by failure. As each school does not offer all curricula, tracking subsequently generates academic segregation between schools. Since unsuccessful students who are oriented in vocational education tend to come more frequently from a 
low socioeconomic milieu, such an academic segregation is coupled with a socioeconomic one.

Having briefly presented the organization on the educational system, we can now focus on Brussels. In the Belgian institutional system, the case of Brussels is complex. Brussels has two official languages (Dutch and French). Consequently, there are two educational systems in the same city, but about $85 \%$ of the students in full-time regular secondary education were enrolled in French-speaking schools in 2008-2009 (last year for which we had access to statistical yearbooks of both communities). Since our data covers only students enrolled in schools of the French-speaking educational system, we have to stress that this paper does not cover all students and schools from the Brussels area.

The city provides an interesting case study as it consists of a small, coherent but segregated market with a dense offer (figure 1). In terms of the density of pupils' population, Brussels welcomes about 4 French-speaking pupils in primary education by hectare while this density only reaches .14 pupil by hectare in Wallonia (namely, the region gathering all the other markets) (Danhier, 2016). Brussels has the widest dispersion in terms of the socioeconomic background of its population: a highly deprived population coexists with a highly privileged population in a limited area of the city. Brussels also has the widest dispersion in terms of socioeconomic school composition since schools from both ends of the distribution lie in Brussels while this range is lower in other Belgian areas. Consequently, school attractiveness for both students and teachers largely differ from one school to the other. Some schools attract students living far away and thus have endless waiting lists. Also, deprived schools tend to have less experienced and less stable educational staff than other schools (Danhier, 2016) as it can be hypothesized that teachers in these schools tend to leave as soon as possible for more privileged work environment. Researchers who proposed several scenarios to identify school market areas (Delvaux et al., 2005) based on the analysis of interdependence links between catchment school areas in the Wallonia-Brussels Federation, have identified Brussels as a specific and coherent area. Although there is some interdependence with the nearest cities in the south, Brussels is separated from the rest of the WalloniaBrussels Federation by a strip of (Dutch-speaking) land of at least $3.5 \mathrm{~km}$, creating a geographical discontinuity. Actually, Brussels is institutionally defined as a bilingual region enclosed in a Dutch-speaking region, though an extended urban area includes the nearest municipalities from both Flanders and Wallonia (two other regions in Belgium, principally monolingual) (Dujardin, Selod \& Thomas, 2008). 
Figure 1. Schools and neighbourhoods in Brussels.

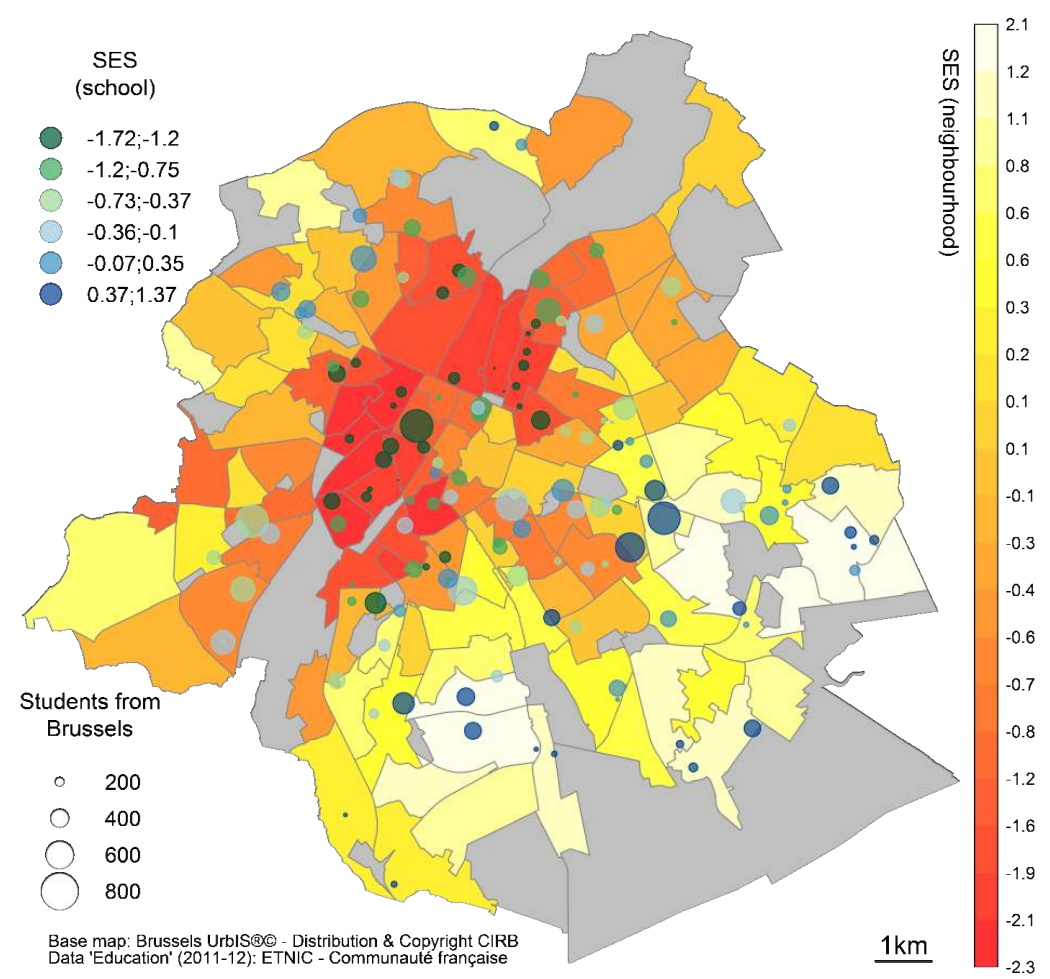

11 As we can see in figure 1, there is a relative matching between the socioeconomic level of the neighbourhoods and the one of the schools. Two patterns are worth noting. A lot of deprived schools are in low socioeconomic neighbourhoods composing what is called the "poor crescent" (in the centre and north-west of Brussels). A second group of schools, including the more privileged ones, are concentrated in an arc in the south-east (Marissal, 2014). This arc accommodates students from the south of Brussels, including the south-east - where only few schools are available. However, some schools in deprived areas accommodate students from more advantaged neighbourhoods. We can interpret this map as showing that students from deprived neighbourhoods go to school in their own neighbourhood. Because of the presence of favoured schools in deprived sectors and the concentration that seems to be higher for deprived schools, we can expect that students from higher socioeconomic background cover higher distances to reach their school. In the next sections, we will challenge this first interpretation.

\section{Data From the Student Count}

One source of data of the French-speaking educational system of Belgium allows us to study the local embeddedness of deprived students: the so-called "comptage des élèves" ( Student count database). On each $15^{\text {th }}$ January, the administrative services endorse a dataset that lists all students attending kindergarten, primary and secondary schools. This database is used for the allocation of federal funding between the Belgian communities and for the management of French-speaking education (as well as for affirmative action). It allows knowing roughly where each student is in the educational system. This database is unique in the Wallonia-Brussels Federation because it covers the 
whole student population at a disaggregated level. Access is restricted to protect privacy, but researchers may use it for specific projects and for a limited period of time. It is important to note that the Student count dataset was set up for management purposes by the administration, not for statistics or analyses. While its uses have been expanded in recent years, the number of variables has remained limited. This forces researchers to be imaginative in order to bring this big dataset in new fields, especially since there is no other existing alternative at the individual level. A fortiori, such a dataset is the only available one that allows to check Devleeshouwer's (2014) findings and assess how the neighbourhood belonging influences student mobility.

For this study we accessed the data of the 66,066 students living in Brussels attending secondary education in the Wallonia-Brussels Federation during the academic year 2011-12. We selected only 63,585 students in schools in Brussels. In addition, we limited our analysis to full-time regular secondary education and excluded the students with special needs (2174 students) and part-time tracks (1048 students). As we were interested in the structure of the school offer, we limited our analysis to the range of the third to sixth grades of secondary education in both general and vocational tracks. This selection constitutes the main streams of Belgian secondary education, whose offer is well developed in the entire city of Brussels (37 498 students, after the exclusion of 33 inconsistent lines). These streams are offered in 131 schools (called "implantation" and that could be represented by a building at a specific address). Two features of this stream have to be noted. Firstly, it is well known that the distance between home and school is greater at this level (compared to primary education) and secondly, the students reach an age where they can go to school by themselves. Consequently, we can expect that geographical constraints are less important at this educational level.

Let us note that the exclusion of students living in Brussels and being schooled outside of Brussels is a strong limitation of our study. As we can see in figure 2 (the proportion of students going to a school of the Wallonia-Brussels Federation outside of Brussels, for each sector), this only concerns a small proportion of students, yet a pattern appears in the southern sectors, which have a high socioeconomic status. Indeed, a .30 correlation between the socioeconomic level of a sector and its proportion of students going to school outside of Brussels. However, without having data from Dutch-speaking Community in order to be able to observe the full pattern of mobility in the extended urban area and because there is a geographical discontinuity between Brussels and the nearest French-speaking cities in the south, there is a risk of distortion of our results, so we decided to limit ourselves to the institutional definition of Brussels. Nevertheless, this choice probably leads to an underestimation of the mobility of students from the privileged neighbourhood at the borders of Brussels. 


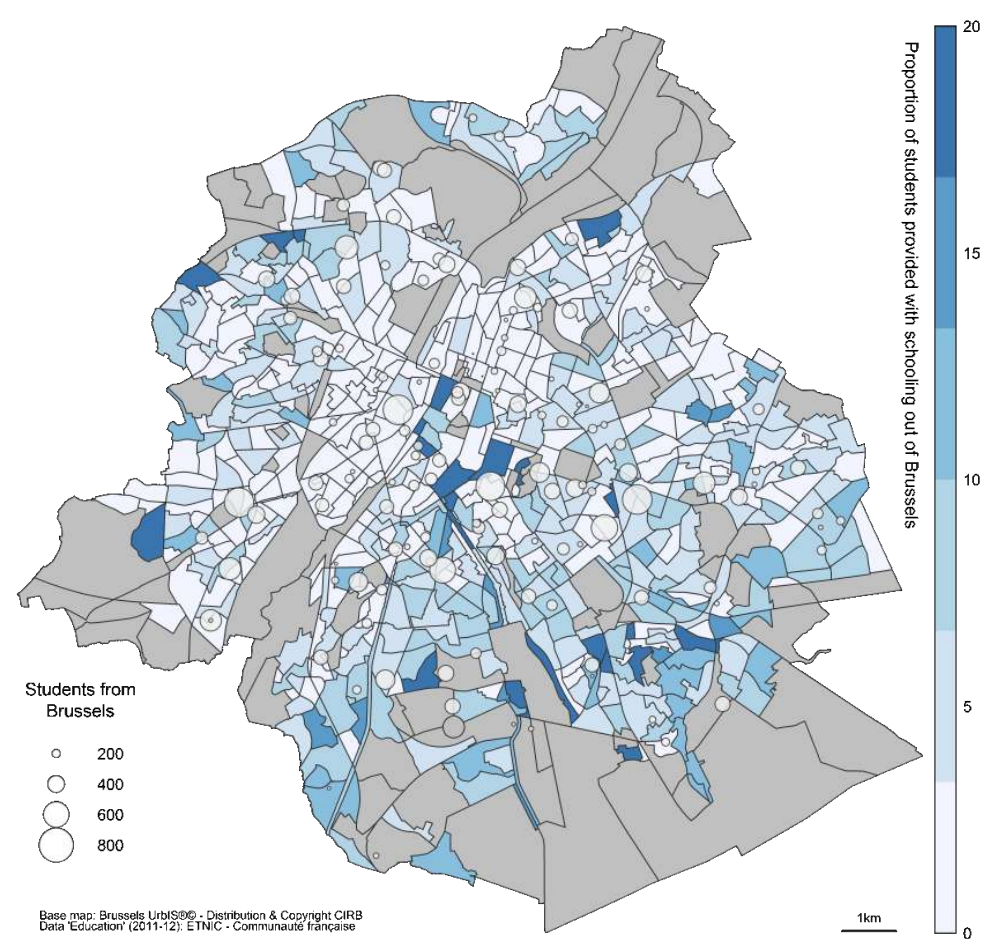

In order to grasp information on urban areas, we used two different categories: the district (figure 1) and the statistical sector (figure 2). Firstly, the district is a local area especially created to observe the urban reality of Brussels. This area defined in the framework of the so-called "monitoring des quartiers" (neighbourhoods monitoring), aims at providing a level that is small enough to approach the urban reality but also sufficiently coherent to allow taking peoples' sense of belonging into account. There are 118 housing districts in Brussels whose surface ranges between .2 and $3.9 \mathrm{~km}^{2}$ (with a median of $.8 \mathrm{~km}^{2}$ ) and with populations of 10 to 19-year-olds ranging between 28 and 2902 in 2010 (with a median of 888). Secondly, the statistical sector is the smallest territorial subdivision defined by the national institute of statistics on the basis of social, economic and geographical features. There are 640 (out of 724) sectors in the housing district in Brussels, whose surface ranges between .01 and $2.7 \mathrm{~km}^{2}$ (with a median of $.14 \mathrm{~km}^{2}$ ). In these analyses, we decided to use the district as the neighbourhood. Data from sectors are included at the individual level.

In the Student count dataset, distances can be estimated with some errors. Due to privacy issues, students' addresses are not available but only their home sector. 242 students could not be included in this study because there was no sufficient data to identify the home sector or the housing neighbourhood. The walking distance was thus computed, using Google, between the centre of the sector and the school address. Consequently, distances will be more reliable for students in small sectors and for students living near the centre of their sector. In order to assure a maximum reliability, we excluded 829 students from big sectors ( 20 sectors have a size greater than $.5 \mathrm{~km}^{2}$ ). Let us note that, in order to control the bias due to sector size, this variable is included in all the models though it does not alter the results. 
17 Information about socioeconomic background is of prime importance for our analyses. However, strictly speaking, the Student count does not include any individual socioeconomic variable. There is a socioeconomic index (SES) but this index is an aggregated measure. Within the framework of affirmative action, an SES was computed for each statistical sector. This synthetic factor was developed to "cover the complexity of socioeconomic reality of sectors" (Demeuse, 2002, p. 229) and encompasses the following dimensions: income, education level, living conditions, occupation and employment in the area. Once the sector indexes are computed, each student receives the value from his sector of residence. This indicator allows us to compute its average value at the school and the neighbourhood level. Let us note that the use of data at the sector level introduces a bias. Strictly speaking, in the case of perfect socioeconomic homogeneity within the sectors, no bias would be introduced. Nevertheless, because sectors include a more or less heterogeneous population, the variance of this socioeconomic variable is artificially underestimated (Delvaux, 2003). Moreover, students from a homogeneous sector will be better represented by the index than students from heterogeneous ones. Let us note, however, that the sectors are small entities (especially when we keep only those smaller than $.5 \mathrm{~km}^{2}$ ) and that we observe important variations between them in terms of socioeconomic levels. In other words, the index, although far from perfect, contains some interesting information.

18 If we simply measure the correlation between the neighbourhood reach of a sector (the mean distance covered by the sector's students) and its socioeconomic level, it reaches .20. Due to the presence of some sectors that are densely populated and have a low socioeconomic status and a restricted reach, the weighted correlation (according to the size) reaches .33. In other words, both correlations are small but students from higher socioeconomic backgrounds go a bit further. We will now turn to the multilevel modelling to see if such analyses tell another story.

\section{Cross-Classified Multilevel Modelling}

19 Multilevel modelling has been developed to analyse hierarchical data, such as educational data. Students in the same school are likely to be more similar to each other than to students from other schools. In the same way, we can say that students in the same neighbourhood are likely to be more similar to each other than to students from other neighbourhoods. Both hierarchies have to be simultaneously modelled with crossclassified multilevel modelling (Browne, 2012). Actually, according to simulations (Meyers, Beretvas, 2006), failing to model appropriately cross-classified hierarchies leads to an underestimation of standard errors of the fixed effects at the ignored levels and to biases in the random part, namely, an inflation of the first level variance and the redistribution of the ignored level variance to the other second level. In other words, failing to model the school level would lead to attribute a part of the effect at the student and neighbourhood levels but also to risk to wrongly accept school variables as significant. In this study, cross-classified multilevel analyses have been used on 36427 students in 117 neighbourhoods and 131 schools.

Although we did not find any application of cross-classified modelling to distance between the school and the home, the literature can provide some example of this modelling approach. In the field of education, student achievement has been used as dependent variable. In multilevel analysis, it is common to begin with the intercept-only 
or empty model (without any independent variable) to observe the way the variance is distributed over the specified levels. In Sweden, Brännström (2008) found a modest effect of clustering at the neighbourhood level (3.0\%) but a more substantial one at the school one (22.7\%). Leckie (2009) succeeded in disentangling school and neighbourhood variance in England and found small but significant differences in educational achievement across neighbourhoods. Only $5.3 \%$ of the variance lies at the neighbourhood level while $19.9 \%$ is at the secondary school level. Regarding Dutch native students from secondary education in the Netherlands, Sykes and Musterd (2011) found that $2.4 \%$ of the variance lies at the neighbourhood level while $39.9 \%$ is at the school level. These analyses show that, although the neighbourhood has a significant impact on student achievement, it remains quite limited. However, conclusions could be different using the distance as a dependent variable, an approach we can find outside the field of education. Applying such an approach to study the distance between home and the workplace in Northern Ireland, Shuttleworth and Gould (2010) observed that $45.0 \%$ of the distance variance lies at the neighbourhood level while $28.6 \%$ is at the workplace level. This latter analysis reveals that both origin and destination have to be modelled.

21 We used a similar approach with school distance defined as the dependent variable. Because the distribution of distance is skewed, we used its square root. The results for 4 models are presented in table 1 . Model 0 presents the intercept-only model allowing us to observe the way the variance of distance is distributed over the neighbourhood and school levels. In other words, this model partitions the variation in covered distances as they are attributable to individual characteristics, to living in a specific neighbourhood or to going to a specific school. 
Table 1. Multilevel modelling on distance between the school and the home.

\begin{tabular}{|c|c|c|c|c|}
\hline Parameters & Model 0 & Model 1 & Model 2 & Model 3 \\
\hline \multicolumn{5}{|c|}{ Fixed part } \\
\hline Intercept & $1.58(.050)$ & $1.69(.051)$ & $1.61(.049)$ & $1.25(.044)$ \\
\hline Neighbourhood's SES & & $-.038(.031)$ & $-.038(.031)$ & $-.115(.023)$ \\
\hline School's SES & & $.250(.043)$ & $.302(.041)$ & $.323(.038)$ \\
\hline Delay & & & $.045(.003)$ & $.042(.003)$ \\
\hline Vocational & & & $.076(.009)$ & $.095(.009)$ \\
\hline $\begin{array}{l}\text { Minimum distance to } \\
\text { grade/track }\end{array}$ & & & & $.257(.007)$ \\
\hline $\begin{array}{l}\text { Minimum distance to } \\
\text { school }\end{array}$ & & & & $.110(.019)$ \\
\hline \multicolumn{5}{|c|}{ Random part } \\
\hline Student variance & $.249(.002)$ & $.249(.002)$ & $.246(.002)$ & $.237(.050)$ \\
\hline Neighbourhood variance & $.121(.017)$ & $.120(.017)$ & $.120(.017)$ & $.061(.009)$ \\
\hline School variance & $.176(.022)$ & $.141(.018)$ & $.123(.016)$ & $.106(.014)$ \\
\hline \multicolumn{5}{|c|}{ Goodness of fit } \\
\hline Student explained variance & $0.0 \%$ & $0.0 \%$ & $1.2 \%$ & $4.8 \%$ \\
\hline $\begin{array}{l}\text { Neighbourhood explained } \\
\text { variance }\end{array}$ & $0.0 \%$ & $0.0 \%$ & $0.0 \%$ & $49.2 \%$ \\
\hline School explained variance & $0.0 \%$ & $19.9 \%$ & $30.1 \%$ & $39.8 \%$ \\
\hline DIC & 53025.672 & 53026.285 & 52592.398 & 51114.29 \\
\hline
\end{tabular}

Students are simultaneously nested in schools and neighbourhoods. While the fixed part panel presents the unique effects of the variables included in the model, the random part panel displays the partition of the variance between the levels. The explained variances allow assessing how the model is able to predict the data at each level. The model with the lower DIC value is preferred. Standard errors are in brackets.

In model 1, neighbourhood SES and school SES are introduced. The SES of the home sector is aggregated at both neighbourhood and school levels. Indeed, socioeconomic differences could explain partly the differences in the distance covered by the student. Two hypotheses are explored in this model. Firstly, students living in deprived neighbourhoods have a different mobility to school since there is a stronger local embeddedness in these neighbourhoods. This hypothesis is supported by the literature presented above but challenged by the results of Devleeshouwer (2014) regarding the case of Brussels. Secondly, schools with a privileged population have larger recruiting areas as their more favourable reputation attracts students covering longer distances. This second hypothesis refers to the school typology of Mistiaen and Kesteloot (1998). According to the authors, what is determining is less the localization than the profile or the selectivity of the school, and selective schools with large catchment areas can be opposed to schools with local catchment areas. Although individual characteristics are usually modelled prior to higher level ones, we chose this strategy to show how these coefficients move after the inclusion of individual characteristics in order to discuss the consequences of ignoring such clusters in the modelling process.

In the Belgian French-speaking educational system, students' heterogeneity is managed among others by grade repetition and tracking. The logic behind this is well-known. Unsuccessful students repeat the same year and/or are reoriented from general to vocational education following a sort of waterfall model. These moves in the educational 
hierarchy could force them to search for schools further away from home not only because schools where they can apply are progressively limited but because some tracks are not available around the home. Let us note that the higher probability of deprived students to be unsuccessful students (assigned to specific places in the educational hierarchy and a few years behind those who were maintained in the shorter and more demanding curriculum) can partly compensate for the omission of an individual measure of SES. One dummy variable for vocational education and a delay variable (the number of grades the student has repeated) are subsequently entered at the student level in the model 2.

Finally, we modelled the structure of the educational offer around the house. The first variable is the mean distance between the centroid of the home sector and the 3 nearest schools and measures the availability of schools around the house. The number of schools is arbitrary but in a context of freedom of school choice, it seems to be a good indicator of the minimum distance to cover to be able to exercise such a right. The second variable is the mean distance to cover in order to reach 3 schools organizing classes for a specific grade and track. In other words, we expect that students who must go far to attend a specific class go further than the others. Such an expectation assumes that a student does not only choose a school, but chooses a class and finds a school where it is possible to follow it.

As stated earlier, student level-variable measuring SES is not available. This is a major limit of our analyses. Socioeconomic characteristics could, and they probably do, have an influence at the student's level. All models were run with the sector SES at the student level (the smallest unit for which an SES is available) but the coefficient was not different from zero and the variable was omitted in the following lines.

\section{Results}

The intercept-only model shows that $22.2 \%$ of the distance variance stays between neighbourhoods and $32.2 \%$ between schools. Let us highlight that such values are quite high. In other words, we observe significant differences across neighbourhoods but also across schools in terms of the distance covered by their students. The remainder (45.6\%) lies between students, within schools and neighbourhoods. The intercept can be approximately interpreted as the average distance covered by a student, which means that students cover 1.58 units according to the scale of the transformed dependent variable, namely, more or less $2.5 \mathrm{~km}$ to reach school.

Model 1 presents the effect of schools and neighbourhoods SES on the distance covered by the students. Although the student level is classically specified before other levels in Multilevel modelling, we have chosen another strategy to see how schools and neighbourhoods SES coefficients change. In table 1, the regression coefficients represent the increase in distance that is associated with a one-unit increase in the given predictor, controlling for other variables included in the model. The .25 coefficient indicates that deprived schools tend to have a more locally based catchment area because students tend to cover smaller distances to reach them. On the other hand, students from deprived neighbourhoods do not cover smaller distances than those from more privileged neighbourhoods (the coefficient is not significantly different from 0 ). This means that once the belonging to both the school and the neighbourhood is modelled, students from deprived neighbourhoods cover the same distance to school as students from favoured 
neighbourhood. While the school SES seems to explain an important part of the variance at the school level (19.9\%), the neighbourhood SES does not explain any variance of the distances between neighbourhoods. The DIC value allows us to compare the fit of different models accounting for the number of parameters to estimate. As we would like to obtain the smaller DIC value, we observe that this model does not present a real improvement.

In model 2, variables representing student tracks and grades are introduced. Both variables have a significant positive influence on the distance covered. In other words, being in a vocational track requires the student to cover greater distances, and so does the fact of having repeated one or more grades. Let us underline that such effects are cumulative as the covered distances rise with the number of grade repetitions and the orientation in vocational tracks. According to the DIC, the inclusion of this type of variable improves the model. Let us note that it does not explain a lot of the student variance but a substantive part of the school variance. This is usually the expression of the school segregation process: schools differ by the socio-demographic and achievement characteristics of their population. The school's SES effect then reaches.302. That means that if we take two students with the same school career, the one from the favoured school covers a longer distance than the other.

Finally, we modelled the structure of the offer around the home. The latter variables explain the major part of the variance of distance between neighbourhoods but also a small part of the variance between schools and within schools and neighbourhoods. Logically, bigger distances have to be covered for students who are more isolated regarding the school offer. Regarding the proportion of the neighbourhood variance explained by these variables, the structure of the school offer is clearly not the same in the different neighbourhoods. Let us note that, after including the structure of the school offer, the SES effect becomes higher because of its correlation with the aforesaid structure. As shown, by the results presented in table 1, when controlling for the structure of education, the density of the offer and the school catchment area, the regression coefficient associated with the SES neighbourhood increases. In other words, in this model, students from low socioeconomic neighbourhoods tend, actually, to cover longer distances. Such results may seem counter-intuitive. In other words, when we compare two students located at the same distance of nearest schools (and the same distance of the specific grade and tracks they follow), the student in the disfavoured school tends to cover a longer distance. In other words, the small positive bivariate correlation observed between the neighbourhood's SES and neighbourhood reach is due to the bigger catchment area of privileged schools and the structure of the local school offer around the student home.

Finally, we have to admit that the modelling remains weak, at least to explain differences at the student level. This is partly due to the unavailability of some important variables. Thus, caution is required when interpreting our results. Consequently, it is difficult to draw definite conclusions regarding local embeddedness. Nevertheless, some interesting findings are worth noting. The place of students in the educational system, the SES of the schools, as well as the structure of the school offer, have a noticeable influence on the distance covered between home and school. These variables explain a major part of the variance of distance at the school and neighbourhood levels. 


\section{Conclusion}

31 This paper investigates the question of the neighbourhood effect and school choices: do children from deprived neighbourhoods cover smaller distances to go to school? This hypothesis has been tested by using quantitative data in a specific urban area, Brussels. The student count dataset provides a unique source of data in the Belgian WalloniaBrussels Federation. According to the cross-classified multilevel analyses, an important part of the variance between students in terms of distance covered lies at the school and the neighbourhood levels. In other words, the distance covered by a student depends on the neighbourhood reach and on the school catchment area. Our results go against the dominant idea of local embeddedness in deprived areas. In our opinion this has to be understood in the light of the structural characteristics of the school system (importance of early orientations in different tracks and of delays) but also of the spatial patterns of the school offer in Brussels. This also has to be understood in terms of the opposition between the larger catchment of selective schools against local-based schools that goes along with the opposition between deprived and favoured schools.

These analyses confirm the hypothesis of the role of the structuration of the school offer.

A great part of the variance between schools and the main part of the variance between neighbourhoods is explained by the density of the offer around the student's house. In other words, students living in neighbourhoods with few schools and far away from other neighbourhoods with the biggest offer, cover longer distances to reach their school. As the deprived neighbourhoods are concentrated in the centre of Brussels, the students from these neighbourhoods can access more easily a larger school offer. Finally, the way socioeconomic characteristics of schools and neighbourhoods are associated with distance is puzzling. The small positive link between the neighbourhood's socioeconomic level and the distance covered by students is, on the one hand, spuriously attributed to the neighbourhood if the school is not modelled, and on the other hand, moderated by the structure of the school offer. In this modelling, when the bigger catchment area of the favoured schools is taken into account, students from deprived neighbourhoods tend to cover a slightly bigger distance to reach school.

Brussels is about to face a major crisis of education if nothing is undertaken as the city faces a massive growth of its youth population and as the school offer is far from being sufficient to accommodate it. This context, in combination with the organization of a highly stratified but lowly regulated school system, will exacerbate the differences in accessing the most demanded schools and at the very best, maintain a high level of school segregation, which is problematic in terms of equal opportunities (Danhier et al., 2014). Our results should draw the attention of policymakers on the importance of the way the school system is organized. Certainly, the quantitative repartition of the number of schools has to be rethought as there are some parts of the city with nearly no school offer. Moreover, the kind of school offer has to be equally distributed in the urban area. This distribution could be taken into account when building new schools to cover education needs of the students in Brussels. However, we can doubt that such a distribution of schools in the territory could modify the lower access of deprived students to more demanded schools without tackling the question of differentiated school careers and the way students are allocated to schools. As education is a competence of linguistic communities and not of the territorial government of Brussels, it is capital for the city to 
deeply collaborate with both the linguistic institutions if student mobility is considered as an important political issue.

Our analysis has, however, some serious limitations such as the lack of individual addresses and SES. As a consequence, the school level coefficient should be treated with caution because it could be due to a selection bias. Without any valid variable to measure individual SES, the smaller neighbourhood reach associated with some neighbourhoods could reflect individual characteristics and not a phenomenon at the neighbourhood level. According to Jencks and Mayer (1990), controlling exogenous influences is one of the fundamental problems in estimating neighbourhood effect. The authors advised controlling the family characteristics that matter wherever the child lives. Dietz (2002) picked out several problems in estimating neighbourhood effect. Among them, people sorting in different neighbourhoods (selection bias) and the omission of important variables (omission bias) invite to scepticism when we consider results on neighbourhood effects. Statistical strategies such as using instrumental variables, fixed effect, quasiexperimental design and sensitivity analysis are expected to assure the robustness of the results. However, none of them are possible with our data. This clearly limits the impact of our results. Future research should tend to link the available data in the Student count dataset to survey collection of individual socioeconomic background or to other administrative data to extract such individual characteristics.

\section{BIBLIOGRAPHY}

ANDRÉ G. (2012), L'orientation scolaire : Héritages sociaux et jugements professoraux, Paris, PUF.

BACQUÉ M.-H., FOL S. (2007), "Effets de quartier: enjeux scientifiques et politiques de l'importation d'une controverse”, in AUTHIER J.-Y., BACQUÉ M.-H. \& GUÉRIN-PACE F. (dir.), Le quartier. Enjeux scientifiques, actions politiques et pratiques sociales, Paris, La Découverte.

BELL J. (2003), "Beyond the School Gates: the influence of school neighbourhood on the relative progress of pupils", Oxford Review of Education, 29, 4, pp. 485-502.

BRÄNNSTRÖM L. (2008), “Making Their Mark: The Effects of Neighbourhood and Upper Secondary School on Educational Achievement", European Sociological Review, 24, 4, pp. 463-478.

BROOKS-GUNN J., DUNCAN G.J., KLEBANOV P.K. \& SEALAND N. (1993), "Do neighborhoods influence child and adolescent development?”, American journal of sociology, pp. 353-395.

BROWNE W.J. (2012), MCMC Estimation in MLwiN, Version 2.26, University of Bristol, Centre for Multilevel Modelling.

CARLSON D., COWEN J.M. (2015), "Student neighborhoods, schools, and test score growth: Evidence from Milwaukee, Wisconsin”, Sociology of Education, 88, 1, pp. 38-55.

CLOTFELTER C.T., LADD H.F. \& VIGDOR J.L. (2005), "Who teaches whom? Race and the distribution of novice teachers", Economics of Education Review, 24, 4, pp. 377-392.

CLOTFELTER C.T., LADD H.F., VIGDOR J.L. \& WHEELER J. (2006), "High-Poverty Schools and the Distribution of Teachers and Principals”, North Carolina Law Review, 85, pp. 1345-1380. 
DANHIER J. (2016), “Teachers in Schools with Low Socioeconomic Composition: Are They Really that Different?", European Education, 48, 4, pp. 274-293.

DANHIER J., JACOBS D., DEVLEESHOUWER P., MARTIN E. \& ALARCON A. (2014), Vers des écoles de qualité pour tous? Analyse des résultats à l'enquête PISA 2012 en Flandre et en Fédération WallonieBruxelles, Bruxelles, Fondation Roi Baudouin.

DELUCA S., DAYTON E. (2009), "Switching Social Contexts: The Effects of Housing Mobility and School Choice Programs on Youth Outcomes", Annual Review of Sociology, 35, 1, pp. 457-491.

DELUCA S., ROSENBLATT P. (2010), “Does moving to better neighborhoods lead to better schooling opportunities? Parental school choice in an experimental housing voucher program", The Teachers College Record, 112, 5, pp. 7-8.

DELVAUX B. (2003), “La ségrégation scolaire, phénomène avéré mais mal connu : apports et limites des données disponibles en Belgique francophone”, Cahiers du Service de Pédagogie expérimentale (ULg), 1516, pp. 113-124.

DELVAUX B., DEMEUSE M., DUPRIEZ V., FAGNANT A., GUISSET C., LAFONTAINE D., MARISSAL P. \& MAROY C. (2005), Les bassins scolaires: de l"idée au projet. Propositions relatives aux domaines d'intervention, aux instances et aux territoires, Rapport à la Communauté française de l'étude intitulée "Définition, cartographie, rôles et modes de régulation des bassins scolaires".

DELVAUX B., JOSEPH M. (2006), "Hiérarchie scolaire et compétition entre écoles : le cas d'un espace local belge”, Revue française de pédagogie, 156, pp. 19-27.

DEMEUSE M. (2002), Analyse critique des fondements de l"attribution des moyens destinés à la politique de discrimination positive en matière d'enseignement en Communauté française de Belgique, thèse présentée en vue de l"obtention du titre de Docteur en Sciences psychologiques, sous la direction de Marcel Crahay, Liège, ULg.

DEMEUSE M., FRIANT N. (2010), "School segregation in the French Community of Belgium”, in BAKKER J., DENESSEN E., PETERS D. \& WALRAVEN G. (dir.), International perspectives on countering school segregation, Antwerpen, Garant, pp. 169-187.

DEVLEESHOUWER P. (2014), “Attachement au local et ancrage territorial, un prisme trop restreint pour comprendre le rapport à la ville des jeunes bruxellois", in Bruxelles, ville mosaïque entre espaces, diversités et politiques, Bruxelles, PUB.

DEVLEESHOUWER P., REA A. (2011), "Justification des différenciations scolaires par les acteurs de l'enseignement", Education comparée / Nouvelle série, 6, pp. 49-68.

DIETZ R.D. (2002), “The estimation of neighborhood effects in the social sciences: An interdisciplinary approach”, Social Science Research, 31, 4, pp. 539-575.

DIJKSTRA P., KUYPER H., WERF G. VAN DER, BUUNK A.P. \& ZEE Y.G. van der (2008), “Social Comparison in the Classroom: A Review", Review of Educational Research, 78, 4, pp. 828-879.

DUJARDIN C., SELOD H. \& THOMAS I. (2008), "Residential Segregation and Unemployment: The Case of Brussels", Urban Studies, 45, 1, pp. 89-113.

DUMAY X., DUPRIEZ V. (2008), "Does the school composition effect matter? Evidence from Belgian data", British Journal of Educational Studies, 56, 4, pp. 440-477.

GARNER C.L., RAUDENBUSH S.W. (1991), "Neighborhood Effects on Educational Attainment: A Multilevel Analysis”, Sociology of Education, 64, 4, pp. 251-262. 
HARDING D.J. (2003), "Counterfactual Models of Neighborhood Effects: The Effect of Neighborhood Poverty on Dropping Out and Teenage Pregnancy", American Journal of Sociology, 109, 3, pp. 676-719.

JAMOULLE P., MAZZOCCHETTI J. (2011), Adolescences en exil, Louvain-la-Neuve, HarmattanAcademia.

JENCKS C., MAYER S.E. (1990), "The social consequences of growing up in a poor neighborhood”, in LYNN L.E., MCGEARY M.G.H. (dir.), Inner-city poverty in the United States, Washington D.C., National Academy Press.

LECKIE G. (2009), “The complexity of school and neighbourhood effects and movements of pupils on school differences in models of educational achievement", Journal of the Royal Statistical Society: Series A (Statistics in Society), 172, 3, pp. 537-554.

LUPTON R. (2006), “How does Place affect education?”, in DELORENZI S. (dir.), Going Places: Neighbourhood, Ethnicity and Social Mobility, London, Institute for Public Policy Research.

MARISSAL P. (2014), “La ségrégation entre écoles maternelles. Inégalités entre implantations scolaires : les inégalités sociales entre quartiers ont trop bon dos", Education \& Formation, e-302.

MARSH H.W., PARKER J.W. (1984), "Determinants of student self-concept: is it better to be a relatively large fish in a small pond even if you don"t learn to swim as well?", Journal of Personality and Social Psychology, 47, 1, pp. 213-231.

MEYERS J.L., BERETVAS S.N. (2006), “The Impact of Inappropriate Modeling of Cross-Classified Data Structures”, Multivariate Behavioral Research, 41, 4, pp. 473-497.

MISTIAEN P., KESTELOOT C. (1998), "Socialisation et marginalisation des jeunes de la zone défavorisée de Bruxelles, un accès différencié à l'école", Espace, populations, sociétés, 16, 2, pp. 249-261.

OPDENAKKER M.-C., VAN DAMME J. (2001), "Relationship between school composition and characteristics of school process and their effect on mathematics achievement", British Educational Research Journal, 27, 4, pp. 406-428.

PALARDY G.J. (2015), "High school socioeconomic composition and college choice: multilevel mediation via organizational habitus, school practices, peer and staff attitudes", School Effectiveness and School Improvement, 26, 3, pp. 329-353.

REA A., NAGELS C. (2007), Jeunes à perpète, Louvain-la-Neuve, Academia Bruylant.

SAMPSON R.J., SHARKEY P. \& RAUDENBUSH S.W. (2008), "Durable effects of concentrated disadvantage on verbal ability among African-American children", Proceedings of the National Academy of Sciences, 105, 3, pp. 845-852.

SHARKEY P., ELWERT F. (2011), “The legacy of disadvantage: multigenerational neighborhood effects on cognitive ability”, American Journal of Sociology, 116, 6, pp. 1934-1981.

SHUTTLEWORTH I., GOULD M. (2010), “Distance between home and work: a multilevel analysis of individual workers, neighbourhoods, and employment sites in Northern Ireland", Environment and planning $A, 42,5$, pp. 1221-1238.

SOUZA A.R. DE, LEAL V.C. (2006), Les chemins de l'école: déplacements scolaires dans la région de Bruxelles-Capitale, Louvain-la-Neuve, Presses universitaires de Louvain.

SYKES B., KUYPER H. (2013), "School Segregation and the Secondary-School Achievements of Youth in the Netherlands", Journal of Ethnic and Migration Studies, 39, 10, pp. 1699-1716. 
SYKES B., MUSTERD S. (2011), "Examining Neighbourhood and School Effects Simultaneously: What Does the Dutch Evidence Show?", Urban Studies, 48, 7, pp. 1307-1331.

\section{ABSTRACTS}

This paper investigates the links between the existence of a neighbourhood effect and school choice. The case study is Brussels. It offers the opportunity to analyse a segregated urban context with a school system organized as a quasi-market based on the freedom of school choice. Crossclassified multilevel analyses have been used on 36427 students in 117 neighbourhoods and 131 schools from the Wallonia-Brussels Federation's Student count. Our results challenge the idea of local embeddedness in deprived areas. This should be understood in the light of the structural characteristics of the school system (the importance of delays and of early orientations in alternative tracks) but also of the spatial patterns of the school offer in Brussels, which varies according to one's geographical place in the school system.

Cet article examine l'effet du quartier dans le choix de l'école. La Région de Bruxelles-Capitale en est le terrain d'investigation. Ce cas d'étude offre la possibilité d'analyser un contexte urbain ségrégé dont le système scolaire est caractérisé par son quasi-marché, fondé sur la liberté de choix de l'école. L'analyse multiniveau à double hiérarchie a été utilisée sur les données du comptage des élèves de la Fédération Wallonie Bruxelles (36 427 élèves dans 117 quartiers et 131 écoles). Nos résultats vont à l'encontre de l'idée d'ancrage local dans les quartiers défavorisés. La plus faible distance parcourue par les élèves de ces quartiers doit être comprise à la lumière des caractéristiques structurelles du système scolaire (importance des retards et des premières orientations dans différentes pistes), mais aussi de la configuration spatiale de l'offre scolaire à Bruxelles, différente selon le lieu que l'élève occupe dans le système scolaire.

\section{INDEX}

Mots-clés: éducation, effet de voisinage, choix de l'école, Bruxelles

Keywords: education, neighbourhood effect, school choice, Brussels

\section{AUTHORS}

\section{JULIEN DANHIER}

Université libre de Bruxelles, Group for research on Ethnic Relation, Migration and Equality (GERME), jdanhier@ulb.ac.be

\section{PERRINE DEVLEESHOUWER}

Université libre de Bruxelles, Group for research on Ethnic Relation, Migration and Equality (GERME), perrine.devleeshouwer@ulb.ac.be 